Aım: Behçet's disease (BD) is a systemic immunoinflammatory disorder and the aetiopathogenesis is to be specified. Cytokines play a role in immune response and in many inflammatory diseases. The aim of this case-control study is to investigate serum pro-inflammatory cytokine tumour necrosis factor (TNF)- $\alpha$, interleukin-1beta (IL-1 $\beta$ ), soluble IL-2 receptor (sIL-2R), IL-6, and chemokine IL-8 levels in patients with $B D$. We also determined the end product of lipid peroxidation (malondialdehyde (MDA)) in BD patients as an index for oxidative stress.

Methods: A total of 37 patients (19 men, 18 women) with BD (active, $n=17$; inactive, $n=20$ ) and 20 agematched and sex-matched healthy control subjects (11 men, nine women) included in this cross-sectional, blinded study. Serum TNF- $\alpha$, IL-1 $\beta$, sIL-2R, IL-6 and IL-8 levels were determined by a spectrophotometer technique using the immulite chemiluminescent immunometric assay. Lipid peroxidation was evaluated by Wasowicz et al. The levels of cytokines and lipid peroxidation in the active period were compared with the inactive period of the disease. Results are expressed as mean \pm standard error.

Results: IL-1 $\beta$ levels were below the detection limits of the assay $(<5 \mathrm{pg} / \mathrm{ml})$ in all samples. Mean levels of MDA $(8.1 \pm 0.7 \mu \mathrm{mol} / \mathrm{l})$, sIL-2R $(800 \pm 38 \mathrm{U} / \mathrm{ml})$, IL-6 $(12.6 \pm 1.1 \mathrm{pg} / \mathrm{ml})$, IL-8 $(7.2 \pm 0.4 \mathrm{pg} / \mathrm{ml})$, and TNF- $\alpha$ $(7.9 \pm 0.5 \mathrm{pg} / \mathrm{ml})$ in active BD patients were significantly higher than those in inactive patients $(4.3 \pm$ $0.5 \mu \mathrm{mol} / 1, p<0.01 ; 447 \pm 16 \mathrm{U} / \mathrm{ml}, p<0.001 ; 8.3 \pm$ $0.6 \mathrm{pg} / \mathrm{ml}, p=0.006 ; 5.3 \pm 0.1 \mathrm{pg} / \mathrm{ml}, p<0.001 ;$ and 5.1 $\pm 0.2 \mathrm{pg} / \mathrm{ml}, p<0.001$; respectively) or control subjects $(2.1 \pm 0.2 \mu \mathrm{mol} / 1, p<0.001 ; 446 \pm 20 \mathrm{U} / \mathrm{ml}, p$ $<0.001 ; 6.4 \pm 0.2 \mathrm{pg} / \mathrm{ml}, p<0.001 ; 5.4 \pm 0.1 \mathrm{pg} / \mathrm{ml}, p<$ 0.001 ; and $4.7 \pm 0.1 \mathrm{pg} / \mathrm{ml}, p<0.001$, respectively). On the contrary, only the mean IL-6 level was significantly different between inactive BD and control subjects $(p=0.02)$. All acute phase reactants were significantly higher in active $B D$ than in inactive period (for each, $p<0.01$ ).

Conclusions: High levels of sIL-2R, IL-6, IL-8 and TNF- $\alpha$ indicate the activation of immune system in BD. Serum sIL-2R, IL-6, IL-8 and TNF- $\alpha$ seem to be related to disease activity. Increased lipid peroxidation suggests oxidative stress in BD and therefore tissue damage in such patients. Amelioration of clinical manifestations would be envisaged by targeting these cytokines, chemokines and lipid peroxidation with pharmacological agents.

Key words: Beh et's disease, Chemokine, Cytokine, Immunoassay, Interleukin, Lipid peroxidation

\section{Serum levels of TNF- $\alpha$, sIL-2R, IL-6, and IL- 8 are increased and associated with elevated lipid peroxidation in patients with Behçet's disease}

\author{
Cem Evereklioglu ${ }^{1, C A}$, Hamdi Er², Yusuf Türköz ${ }^{2}$ and \\ Mustafa Cekmen ${ }^{1}$
}

1Department of Ophthalmology, Gaziantep

University Medical Faculty, Research Hospital,

Gaziantep Turkey; and ${ }^{2}$ Department of Biochemistry, Inönü University Medical Faculty, Turgut Ozal

Medical Centre, Research Hospital, Malatya, Turkey

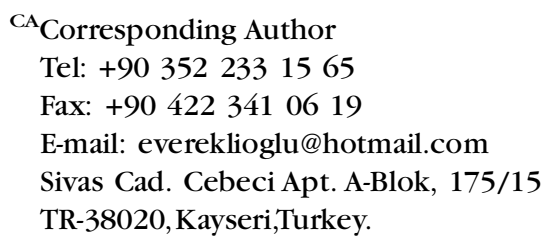

\section{Introduction}

Cytokines are low molecular weight polypeptides involved in the communication between cells. ${ }^{1}$ Abnormal production of some cytokines such as tumour necrosis factor (TNF)- $\alpha$, interleukin-1beta (IL$1 \beta$ ), soluble IL-2 receptor (sIL-2R), IL-6, and chem- okine IL-8 have been implicated in the pathogenesis of various inflammatory and autoimmune diseases. ${ }^{1,2}$ Many in vivo studies have demonstrated that TNF- $\alpha$, IL-1, IL-6, and IL-8 are all important components of the pro-inflammatory response and intraocular inflammation. $^{2}$ Oxidative stress is associated with many systemic inflammatory diseases, and free-radical 
production leads to the formation of self-propagating lipid peroxidation. ${ }^{3}$

Beh et's disease (BD) is a systemic inflammatory disorder of young adults involving small blood vessels (veins and arteries) and is characterised by occlusion in both the deep venous and retinal circulations with unknown aetiology. ${ }^{4}$ After its first description as oral and genital ulceration with hypopyon uveitis in 1937 by the Turkish physician Prof. Dr Hulusi Beh et, ${ }^{5}$ the multisystem character of the disease has well been established. ${ }^{4}$ The classical ocular involvement is iridocyclitis, anterior hypopyon uveitis, retinal vasculitis or panuveitis. In severe ocular disease, the visual prognosis is poor and blindness may occur despite immunosuppressive treatment. Although the aetiopathogenesis of the disease has not yet been clarified, several mechanisms such as genetics, infection, immunoglobulin, immune complexes and antibodies have all been suggested as the causes of BD. ${ }^{4,6}$ It affects almost every tissue and organ in the body without exception, including the cornea, ${ }^{7}$ inner ear ${ }^{8}$ and the lung. ${ }^{9}$ The intermittent nature and the lack of consistent response to therapy make the underlying aetiology difficult to define.

Our previous studies demonstrated that some molecules such as adrenomedullin, ${ }^{10}$ leptin, ${ }^{11}$ and homocysteine ${ }^{12}$ might participate during the course of BD. Furthermore, our more recent study showed that nitric oxide (NO), one of the most abundant free radicals in the body, was significantly increased in $\mathrm{BD}$ and associated with disease activity, suggesting a new activity marker. ${ }^{13}$ Since pro-inflammatory cytokines are known to be the potent inducer of leptin and, therefore, NO from the endothelial cells, it is important to study the levels of these cytokines as well as lipid peroxidation products as a cohort study during the course of BD. Similarly, homocysteine enhances NO synthesis from endothelial cells, induces the expression of chemoattractants by oxygen free radicals, and has important interrelations with cytokines. ${ }^{14}$ Therefore, this study has attempted to overcome these limitations in our understanding by measuring the serum levels of pro-inflammatory cytokines such as TNF- $\alpha$, IL-1 $\beta$, sIL-2R, IL-6 and chemokine IL-8 as well as lipid peroxidation, linking to the state of disease activity. We wished to test the hypothesis that no one factor alone is predominant in the pathophysiology during the course of $\mathrm{BD}$, but that a regular profile of levels of different molecules might be operating together, and that the profile might differ according to disease activity.

\section{Patients and methods}

\section{Study population}

Thirty-seven consecutive patients with BD (19 men, 18 women; mean age, 37.2 years) who attended to the Department of Ophthalmology and/or the Department of Dermatology, and 20 age-matched and sexmatched healthy control subjects (11 men, nine women; mean age, 38.4 years) from a similar ethnic background were included in this study. Subjects with any disorder such as hepatic or renal diseases, diabetes, essential hypertension and pregnancies were excluded from the study. Since medications such as glucocorticosteroids reduce the transcription of the pro-inflammatory cytokines (IL-1, IL-2, IL-6, IL8 , and TNF- $\alpha),{ }^{15}$ a detailed history of drug use was obtained in both groups and, as such, three patients using steroids and two patients using immunosuppressives were not included in the study. The diagnosis of $\mathrm{BD}$ was made according to the criteria for diagnosis of the International Study Group for Behet's Disease ${ }^{16}$ (Table 1). Informed consent was obtained from all subjects in both groups.

Nineteen patients (51.3\%) had severe ocular involvement (anterior hypopyon uveitis/iridocyclitis, retinal vasculitis, cells in the vitreous, or panuveitis). In addition, oral lesions were present in all cases (100\%). Thirty-four patients (91.8\%) had various coetaneous lesions. Articular symptoms were present in 33 patients (89.1\%) and genital ulceration in 31 (83.7\%). Eighteen of 37 patients (48.6\%) showed a positive pathergy test, nine patients (24.3\%) complained of neurological symptoms and one of them (2.7\%) had Neuro-Beh et's. Gastrointestinal system symptoms and signs were present in eight patients (21.6\%).

Since there is no clinically acceptable scoring system and laboratory screening profile to define the severity of $\mathrm{BD}$, active $(n=17)$ and inactive $(n=20)$ BD patients were determined by both clinical and laboratory findings. In clinical evaluation, worsening of clinical symptoms at the time of study and having at least three of the major symptoms (oral ulcers, genital ulcers, skin lesions and uveitis) were considered to be in the active period of the disease. The inactive patients had no any symptoms and signs of disease activity at least 3 months before admission. The diagnosis of uveitis was made according to the International Uveitis Study Group. ${ }^{17}$ In laboratory investigations, the erythrocyte sedimentation rate (ESR), neutrophil count and acute phase reactants ( $\alpha_{1}$-antitrypsin and $\alpha_{2}$-macroglobulin concentrations) were investigated. ${ }^{10-13}$

\section{Neutrophil count, ESR and acute-phase reactants analyses}

This was a double-blind study. Therefore, both the physician taking the blood and the analyser were blinded to the group of the subject. In both groups, antecubital whole blood samples (total, $5 \mathrm{ml}$ ) were obtained by venipuncture from a peripheral vein, avoiding haemolysis, into plain tubes during resting 
Table 1. Clinical findings of patients with active and inactive Behçet's disease: International Study Group for Behçet's disease criteria* for the diagnosis of Behçet's disease

\begin{tabular}{|c|c|c|c|c|c|c|c|c|c|}
\hline No. & Sex & A & $\mathrm{D}$ & $\mathrm{Ou}$ & Coetaneous lesions & $\mathrm{Gu}$ & Path. $\neq$ & Ocular lesions & Other findings \\
\hline $1 \dagger$ & M & 38 & 8 & + & Pseudofolliculitis, acneiform lesions & - & + & Right retinal vasculitis & Migraine headache \\
\hline 2 & W & 44 & 16 & + & $\begin{array}{l}\text { Erythema nodosum, pseudofolliculitis } \\
\text { Acneiform lesions }\end{array}$ & + & + & - & $\begin{array}{l}\text { Arthralgia at the knees } \\
\text { ALP }\end{array}$ \\
\hline $3+$ & W & 22 & 2 & + & Pseudofolliculitis, acneiform lesions & - & + & - & Arthralgia at the ankles \\
\hline $4 \dagger$ & M & 45 & 12 & + & Pseudofolliculitis, acneiform lesions & + & - & Left anterior iridocyclitis & Arthritis at the knees \\
\hline 5 & $\mathrm{M}$ & 52 & 24 & + & - & + & - & Bilateral panuveitis & $\begin{array}{l}\text { Migraine headache } \\
\text { Sacroiliitis }\end{array}$ \\
\hline $6+$ & W & 52 & 21 & + & Erythema nodosum, pseudofolliculitis & - & + & - & $\begin{array}{l}\text { Neuro-Behçet's, arthralgia at the } \\
\text { knees and ankles }\end{array}$ \\
\hline 7 & W & 35 & 6 & + & Acneiform lesions & + & + & - & Arthralgia at the knees \\
\hline 8 & M & 34 & 7 & + & Pseudofolliculitis, acneiform lesions & + & + & - & Arthralgia at the knees \\
\hline $9 \dagger$ & $\mathrm{M}$ & 29 & 4 & + & Acneiform lesions, thrombophlebitis & + & - & Right hypopyon uveitis & Arthritis at the knees \\
\hline 10 & M & 26 & 3 & + & Pseudofolliculitis, acneiform lesions & + & - & Left retinal vasculitis & Arthritis at the ankles \\
\hline 11 & W & 44 & 10 & + & $\begin{array}{l}\text { Erythema nodosum, thrombophlebitis } \\
\text { Pseudofolliculitis, acneiform lesions }\end{array}$ & + & + & - & $\begin{array}{l}\text { Sacroiliitis } \\
\text { ALP }\end{array}$ \\
\hline $12 \dagger$ & $\mathrm{M}$ & 33 & f8 & + & Pseudofolliculitis, acneiform lesions & + & - & Bilateral retinal vasculitis & Migraine headache \\
\hline 13 & M & 32 & 7 & + & Thrombophlebitis, pseudofolliculitis & + & - & - & ALP \\
\hline 14 & W & 25 & 3 & + & Pseudofolliculitis, acneiform lesions & + & + & - & Swelling in both knees \\
\hline $15 \dagger$ & W & 45 & 12 & + & - & + & + & Left hypopyon uveitis & Arthritis at the knees \\
\hline $16 \dagger$ & $\mathrm{M}$ & 36 & 11 & + & Pseudofolliculitis, acneiform lesions & + & + & $\begin{array}{l}\text { Bilateral vitreal cells } \\
\text { Right hypopyon uveitis }\end{array}$ & $\begin{array}{l}\text { Arthralgia at the ankles } \\
\text { ALP }\end{array}$ \\
\hline 17 & W & 26 & 2 & + & Pseudofolliculitis, acneiform lesions & + & + & - & $\begin{array}{l}\text { Migraine headache, Arthralgia at } \\
\text { the knees }\end{array}$ \\
\hline 18 & W & 52 & 21 & + & Erythema nodosum, thrombophlebitis & + & - & Bilateral retinal vasculitis & Arthralgia at the knees \\
\hline $19 \dagger$ & $\mathrm{M}$ & 45 & 15 & + & $\begin{array}{l}\text { Erythema nodosum, thrombophlebitis } \\
\text { Acneiform lesions }\end{array}$ & + & + & - & $\begin{array}{l}\text { Melena } \\
\text { Arthralgia at the right knee }\end{array}$ \\
\hline 20 & $\mathrm{M}$ & 45 & 17 & + & Pseudofolliculitis & + & - & Bilateral retinal vasculitis & Arthralgia at the knees \\
\hline 21 & $\mathrm{M}$ & 34 & 8 & + & Erythema nodosum & + & - & Right iridocyclitis & Arthritis at the ankles and fingers \\
\hline $22 \dagger$ & W & 56 & 25 & + & $\begin{array}{l}\text { Erythema nodosum, thrombophlebitis } \\
\text { Pseudofolliculitis, acneiform lesions }\end{array}$ & + & + & - & Sacroiliitis \\
\hline 23 & W & 25 & 3 & + & $\begin{array}{l}\text { Erythema nodosum, thrombophlebitis } \\
\text { Pseudofolliculitis, acneiform lesions }\end{array}$ & + & - & - & Migraine headache \\
\hline 24 & $\mathrm{M}$ & 36 & 11 & + & - & + & - & Bilateral retinal vasculitis & $\begin{array}{l}\text { Arthralgia at the knees and fingers } \\
\text { Left anterior uveitis }\end{array}$ \\
\hline 25 & W & 35 & 9 & + & $\begin{array}{l}\text { Thrombophlebitis, pseudofolliculitis } \\
\text { Acneiform lesions }\end{array}$ & - & + & Bilateral iridocyclitis & $\begin{array}{l}\text { Melena } \\
\text { Arthralgia at the knees }\end{array}$ \\
\hline $26 \dagger$ & W & 19 & 1 & + & Pseudofolliculitis, acneiform lesions & + & + & - & Arthralgia at the knees and fingers \\
\hline $27 \dagger$ & $\mathrm{M}$ & 33 & 9 & + & Pseudofolliculitis, acneiform lesions & + & - & Bilateral retinal vasculitis & Arthralgia at the knees \\
\hline $28+$ & W & 38 & 11 & + & Pseudofolliculitis, acneiform lesions & + & - & - & Arthralgia at the fingers \\
\hline 29 & W & 36 & 7 & + & Pseudofolliculitis & + & - & - & $\begin{array}{l}\text { Migraine headache } \\
\text { Arthralgia at the fingers }\end{array}$ \\
\hline $30 \dagger$ & $\mathrm{M}$ & 31 & 5 & + & $\begin{array}{l}\text { Thrombophlebitis, pseudofolliculitis } \\
\text { Acneiform lesions }\end{array}$ & + & - & Left retinal vasculitis & $\begin{array}{l}\text { Arthralgia at the knees } \\
\text { ALP }\end{array}$ \\
\hline 31 & W & 46 & 15 & + & $\begin{array}{l}\text { Erythema nodosum, thrombophlebitis } \\
\text { Pseudofolliculitis }\end{array}$ & + & - & - & $\begin{array}{l}\text { Ankylosing spondylitis } \\
\text { ALP }\end{array}$ \\
\hline 32 & $\mathrm{M}$ & 26 & 3 & + & Pseudofolliculitis, acneiform lesions & - & + & - & Arthralgia at the knees \\
\hline $33+$ & $\mathrm{M}$ & 45 & 13 & + & $\begin{array}{l}\text { Erythema nodosum, pseudofolliculitis } \\
\text { Acneiform lesions }\end{array}$ & + & - & Right iridocyclitis & Arthralgia at the knees \\
\hline $34 \dagger$ & W & 41 & 15 & + & $\begin{array}{l}\text { Thrombophlebitis, pseudofolliculitis } \\
\text { Acneiform lesions }\end{array}$ & + & - & Left anterior uveitis & Arthralgia at the knees and ankles \\
\hline 35 & $\mathrm{M}$ & 41 & 12 & + & Pseudofolliculitis, acneiform lesions & + & + & Bilateral iridocyclitis & $\begin{array}{l}\text { Migraine headache } \\
\text { Arthralgia at the left knee }\end{array}$ \\
\hline 36 & W & 32 & 8 & + & Pseudofolliculitis, acneiform lesions & - & + & - & $\begin{array}{l}\text { Migraine headache } \\
\text { Arthralgia at the right knee }\end{array}$ \\
\hline $37 \dagger$ & $\mathrm{M}$ & 36 & 11 & + & Erythema nodosum, pseudofolliculitis & + & - & Bilateral iridocyclitis & Arthralgia at the knees \\
\hline
\end{tabular}

A, Age (years); D, disease duration (years); Ou, recurrent oral aphthous ulceration; Gu, recurrent genital ulceration; Path., pathergy test; $\mathrm{M}$, men; W, women, ALP, appendicitis-like pain.

* Ou plus two of the following criteria (Gu, ocular lesions, coetaneous lesions, pathergy test positivity)

†Active patients with Behçet's disease.

‡ Observation of a pustular lesion by physician at $24-48 \mathrm{~h}$ after needle-stick. 
position in the morning hours (08.00-10.00 $\mathrm{h}$ ) after an overnight fast and $30 \mathrm{~min}$ of supine rest. None of the patients and healthy control subjects was receiving any topical or systemic medication on admission. Following centrifugation of the first half of the blood samples $(2.5 \mathrm{ml})$ at $800 \times g$ for $10 \mathrm{~min}$, serum was separated and kept at $-20^{\circ} \mathrm{C}$ until the time of analysis.

The other half of the blood samples $(2.5 \mathrm{ml})$, with ethylenediamine tetraacetic acid $(1 \mathrm{mg} / \mathrm{ml})$ anticoagulant was used for the neutrophil counting by an automated blood counter (Coulter-STKS, Luton, UK). $\alpha_{1}$-Antitrypsin and $\alpha_{2}$-macroglobulin concentrations were measured in the serum by a Behring nephelometer 100 analyser (Dade Behring, Messer Griesheim, Frankfurt, Germany). The ESR was determined by the classical Westergren method.

\section{Cytokine and chemokine analyses}

Cytokine analysis was performed according to the Immulite ${ }^{\circledR}$ (Diagnostic Products Corporation, Los Angeles, CA, USA) chemiluminescent enzyme immunometric assay. The technique is based on a solid-phase (bead) two-site assay. The solid phase, a polystyrene bead, is coated with either a monoclonal specific antibody (TNF- $\alpha$, IL-1 $\beta$ ) or an anti-ligand (sIL-2R, IL-6, IL-8). Patient serum and alkaline phosphatase-conju gated monoclonal antibody or ligand-labelled antibody are incubated for $30-60 \mathrm{~min}$ at $37^{\circ} \mathrm{C}$. Unbound conjugate is then removed by a centrifugal wash (three times), after which a chemiluminescent substrate (a phosphate ester of adamantyl dioxetane) is added and the test unit is incubated for a further $10 \mathrm{~min}$. The Immulite system automatically handles sample and reagent additions, the incubation and separation step, and measurement of the photon output via the temperature-controlled luminometer. It calculates test results for control and patient samples from the observed signal, using a stored master curve, and generates a printed report. ${ }^{18}$ The values of the interassay imprecision study were similar to those from the intra-assay study with coefficient of variation (CV) ranging from 2 to $11.5 \%$. CVs for the measured cytokines were usually around $5 \%$. The linearity is satisfactory, with a regression coefficient higher than $0.99\left(r^{2}\right)$; slopes close to 1.0 were obtained. There is an excellent practicality of the system and good stability of the calibration curve (15 days). It is a good reliable method yielding a good precision along with a satisfactory detection limit. ${ }^{19}$ The antibodies used in the Immulite ${ }^{\circledR}$ forTNF- $\alpha$, IL-1 $\beta$, sIL-2R, IL-6, and IL-8 are highly specific for each cytokine and chemokine, with no cross-reactivity to other cytokines that may be present in the serum samples.

For each new cytokine calibration, a master curve is constructed by the manufacturer using a material calibrated against the National Institute for Biological Standards and Control. For each new cytokine reagent lot, an adjustment of the calibration slope is made by the user by measuring two serum matrix vials (low and high) designated as 'adjusters'. It should be mentioned that between-run and within-run imprecision data were similar, which is very important for stat measurement.

\section{Thiobarbituric acid-reactive substances analysis}

The plasma malondialdehyde (MDA) level, referred to as thiobarbituric acid-reactive substances (TBARS), was measured according to the method described by Wasowicz et al. ${ }^{20}$ In brief, $50 \mathrm{ml}$ of sample or an adequate volume of MDA working standard solution was introduced into $10 \mathrm{ml}$ glass tubes containing $1 \mathrm{ml}$ of distilled water. After addition of $1 \mathrm{ml}$ of the solution containing $29 \mathrm{mmol} / \mathrm{l}$ of TBARS in acetic acid and mixing, the samples were placed in a water bath and heated for $1 \mathrm{~h}$ at $95-100^{\circ} \mathrm{C}$. After the samples were cooled, $25 \mu \mathrm{l}$ of $5 \mathrm{~mol} / \mathrm{l} \mathrm{HCl}$ was added, and the reaction mixture was extracted by agitation for $5 \mathrm{~min}$ with $3.5 \mathrm{ml}$ of $n$-butanol. The butanol phase was separated by centrifugation at $1500 \times g$ for $10 \mathrm{~min}$. The butanol extract was measured with a spectrofluorometer (F-4010 fluorescence spectrophotometer; Hitachi, Tokyo, Japan) at wavelengths of $525 \mathrm{~nm}$ for excitation. The calibration curve was prepared with MDA standards of $0-10 \mu \mathrm{mol} / \mathrm{l}$. Intra- and interassay CVs were 3.5 and 6\%, respectively.

\section{Statistical analysis}

Results were analysed statistically by using the analysis of variance or the Mann-Whitney $U$-test as indicated, and were expressed as mean \pm standard error (range). $p<0.05$ was considered a significant difference between the groups. Statistical analysis was performed with the Statistical Package for the Social Sciences for Windows (version 8.0; SPSS Inc., Chicago, IL, USA).

\section{Results}

For IL-1 $\beta$, all samples in both groups were below the detection limits of the assay $(<5 \mathrm{pg} / \mathrm{ml})$. sIL-2R levels ranged from 347 to $1076 \mathrm{U} / \mathrm{ml}$, with the highest values observed in the active BD patients. Mean sIL-2R concentration in active $\mathrm{BD}$ patients was $800 \pm 38 \mathrm{U} / \mathrm{ml}$ and the difference was significant when compared with inactive patients $(447 \pm 16 \mathrm{U} / \mathrm{ml}, p<0.001)$ or healthy control subjects $(446 \pm 20 \mathrm{U} / \mathrm{ml}, p<0.001)$ (Table 2). IL-6 concentrations ranged from 5 to $22.5 \mathrm{pg} / \mathrm{ml}$, with the highest values observed in the active $\mathrm{BD}$ patients, and the mean values in active patients $(12.6 \pm 1.1 \mathrm{pg} / \mathrm{ml})$ were significantly higher than those in inactive patients $(8.3 \pm 0.6 \mathrm{pg} / \mathrm{ml}, p=$ $0.006)$ or control subjects $(6.4 \pm 0.2 \mathrm{pg} / \mathrm{ml}, p<0.001)$. Mean IL-8 concentrations were found to be higher in patients with active $\mathrm{BD}(7.2 \pm 0.4 \mathrm{pg} / \mathrm{ml})$ than in 
Table 2. MDA, TNF- $\alpha$, IL-1 $\beta$, sIL-2R, IL-6 and IL-8 levels in patients with Behçet's disease and control subjects, and the relation with disease activity

\begin{tabular}{|c|c|c|c|c|c|c|c|c|c|}
\hline Group & $n$ & $\begin{array}{c}\text { Age } \\
\text { (years) } \\
\text { (range) }\end{array}$ & $\begin{array}{c}\text { Men/ } \\
\text { women }\end{array}$ & $\begin{array}{c}\text { MDA } \\
(\mu \mathrm{mol} / \mathrm{l}) \\
(\mathrm{mean} \\
\pm \mathrm{SE})\end{array}$ & $\begin{array}{c}\text { IL-1 } \\
(\mathrm{pg} / \mathrm{ml}) \\
(\mathrm{mean} \\
\pm \mathrm{SE})\end{array}$ & $\begin{array}{c}\text { slL-2R } \\
(\mathrm{U} / \mathrm{ml}) \\
(\mathrm{mean} \pm \\
\text { SE [range]) }\end{array}$ & $\begin{array}{c}\text { IL-6 } \\
(\mathrm{pg} / \mathrm{ml}) \\
(\text { mean } \pm \\
\text { SE [range]) }\end{array}$ & $\begin{array}{c}\text { IL-8 } \\
(\mathrm{pg} / \mathrm{ml}) \\
(\text { mean } \pm \\
\text { SE [range]) }\end{array}$ & $\begin{array}{c}\text { TNF- } \alpha \\
\text { (pg/ml) } \\
\text { (mean } \pm \\
\text { SE [range]) }\end{array}$ \\
\hline Active BD* & 17 & $\begin{array}{c}37.8 \\
(19-56)\end{array}$ & $10 / 7$ & $8.1 \pm 0.7$ & $<5.0$ & $\begin{array}{c}800 \pm 38 \\
(465-1076)\end{array}$ & $\begin{array}{l}12.6 \pm 1.1 \\
(6.0-22.5)\end{array}$ & $\begin{array}{c}7.2 \pm 0.4 \\
(5.2-11.2)\end{array}$ & $\begin{array}{c}7.9 \pm 0.5 \\
(4.9-12.2)\end{array}$ \\
\hline$p$ valuet & & & & $<0.01$ & NS & $<0.001$ & 0.006 & $<0.001$ & $<0.001$ \\
\hline Inactive BD & 20 & $\begin{array}{c}36.3 \\
(25-52)\end{array}$ & $9 / 11$ & $4.3 \pm 0.5$ & $<5.0$ & $\begin{array}{r}447 \pm 16 \\
(347-563)\end{array}$ & $\begin{array}{l}8.3 \pm 0.6 \ddagger \\
(5.0-14.7)\end{array}$ & $\begin{array}{l}5.3 \pm 0.1 \\
(5.0-6.5)\end{array}$ & $\begin{array}{l}5.1 \pm 0.2 \\
(4.0-7.4)\end{array}$ \\
\hline$p$ valuef & & & & NS & NS & NS & 0.02 & NS & NS \\
\hline $\begin{array}{l}\text { Control } \\
\text { subjects }\end{array}$ & 20 & $\begin{array}{c}38.4 \\
(25-56)\end{array}$ & $11 / 9$ & $2.1 \pm 0.2$ & $<5.0$ & $\begin{array}{r}446 \pm 20 \\
(248-605)\end{array}$ & $\begin{array}{l}6.4 \pm 0.2 \\
(5.0-8.5)\end{array}$ & $\begin{array}{c}5.4 \pm 0.1 \\
(5.0-7.4)\end{array}$ & $\begin{array}{c}4.7 \pm 0.1 \\
(4.0-7.1)\end{array}$ \\
\hline
\end{tabular}

NS, not significant; SE, standard error.

* Mean values for all parameters (except IL-1 $\beta$ ) were significantly (for each, $p<0.001$ ) higher than control subjects by analysis of variance.

t Statistical values between active and inactive BD subjects by analysis of variance.

¥ Statistical values between inactive patients and control subjects by analysis of variance.

patients with inactive $\mathrm{BD}(5.3 \pm 0.1 \mathrm{pg} / \mathrm{ml}, p<0.001)$ and control subjects $(5.4 \pm 0.1 \mathrm{pg} / \mathrm{ml}, p<0.001)$. The highest TNF- $\alpha$ concentrations were observed in patients with active $\mathrm{BD}$ and the mean value $(7.9 \pm$ $0.5 \mathrm{pg} / \mathrm{ml}$ ) was significantly higher than inactive BD $(5.1 \pm 0.2 \mathrm{pg} / \mathrm{ml}, p<0.001)$ or control subjects $(4.7 \pm$ $0.1 \mathrm{pg} / \mathrm{ml}, p<0.001)$. Mean MDA levels were also significantly higher in active $\mathrm{BD}(8.1 \pm 0.7 \mu \mathrm{mol} / \mathrm{l})$ than in inactive $\mathrm{BD}(4.3 \pm 0.5 \mu \mathrm{mol} / 1, p<0.01)$ or control subjects $(2.1 \pm 0.2 \mu \mathrm{mol} / 1, p<0.001)$. Mean MDA, sIL2R, IL-8 and TNF- $\alpha$ levels in patients with inactive BD were not higher (for each, $p>0.05$ ) when compared with the control subjects, unlike IL-6 $(p=0.02)$.

There were statistically significant (for each, $p<$ 0.01) differences for acute-phase reactants between active and inactive periods of the disease (Table 3).

\section{Discussion}

The main pathology in $\mathrm{BD}$ is an inflammatory process of small arteries and veins and thrombosis as a result of vasculitis of the vaso vasorum. ${ }^{21}$ The immune system is involved and activated in the course of disease, since increased immunoglobulins, immune complexes, complement and acute phase proteins have all been reported. ${ }^{4,6}$ Abnormalities of neutrophils, endothelial cells, or both, have been suggested to be responsible for many of the clinical manifestations of $\mathrm{BD} .{ }^{22}$ Activation of circulating $\mathrm{T}$ and B lymphocytes also occurs, and these immunoactive cells infiltrate into the affected regions followed by a second phase of neutrophil chemotaxis. ${ }^{4,6}$ Although there is no definitive treatment of $\mathrm{BD}$, hydrocortisone, colchicine, cyclosporin and cyclophosphamide have been used to subside the symptoms and signs of the disease. ${ }^{4,6}$ Given this immunological activity in $\mathrm{BD}$, pro-inflammatory cytokines and mediators may be effected in the course of the disease.

IL-1 $\beta(17 \mathrm{kDa})$ regulates systemically the metabolic, immuno-inflammatory and reparative properties, and can be a mediator of some diseases. ${ }^{23}$ It is secreted by monocytes and tissue macrophages, and is involved in the activation of $\mathrm{T}$ cells. ${ }^{24}$ Control of IL-1 synthesis or its effects becomes a target of therapy in many diseases. ${ }^{25}$ However, this study showed that IL-1 $\beta$ levels of BD patients and control subjects were below the detection limits of the assay $(5 \mathrm{pg} / \mathrm{ml})$ in all samples.

Table 3. Neutrophil count, erythrocyte sedimentation rate and acute-phase reactant levels in patients with active or inactive Behçet's disease compared with control subjects

\begin{tabular}{lrrr}
\hline & $\begin{array}{c}\text { Active BD } \\
(n=17)\end{array}$ & $\begin{array}{c}\text { Inactive BD } \\
(n=20)\end{array}$ & $\begin{array}{c}\text { Controls } \\
(n=20)\end{array}$ \\
\hline Neutrophil Count $\left(10^{3} / \mathrm{ml}\right)$ & $6.2 \pm 0.3^{*}+$ & $3.4 \pm 0.1 \dagger$ & $2.9 \pm 0.1$ \\
Erythrocyte sedimentation rate $(\mathrm{mm} / 1 \mathrm{~h})$ & $36.0 \pm 1.6^{* \dagger}$ & $20.4 \pm 0.7 \dagger$ & $9.9 \pm 0.6$ \\
$\alpha_{1}$-Antitrypsin $(\mathrm{mg} / \mathrm{dl})$ & $231.7 \pm 8.3^{*}+$ & $160.4 \pm 4.0 \dagger$ & $127.2 \pm 3.2$ \\
$\alpha_{2}$-Macroglobulin $(\mathrm{mg} / \mathrm{dl})$ & $275.5 \pm 6.1^{* \dagger}$ & $214.9 \pm 3.5 \dagger$ & $159.7 \pm 5.7$ \\
\hline
\end{tabular}

Data presented as mean \pm standard error.

* Significantly different from the inactive period by analysis of variance (for each, $p<0.01$ ).

† Significantly different from the control subjects by Mann-Whitney $U$-test (for each, $p<0.01$ ). 
The sIL-2R is a smaller $(45 \mathrm{kDa})$ polypeptide than the membrane-bound IL-2R (55 kDa), and has a potential role in the modulation of immune responses by inhibiting IL-2. ${ }^{26}$ Immunosuppressive agents such as hydrocortisone, cyclosporin and cyclophosphamide, which are widely used in the treatment of BD, downregulate the synthesis of IL-2. ${ }^{4}$ Clinically, high levels of sIL-2R are believed to be associated with a potent activation of the immune system in many diseases such as atopic dermatitis and psoriasis. ${ }^{27}$ In the present study, serum levels of sIL-2R were significantly higher in patients with BD when compared with control subjects. In addition, serum sIL-2R levels were significantly higher in active patients than in inactive patients with BD. We think that high serum levels of sIL-2R in the active period indicate the activation of the immune system in $\mathrm{BD}$ and may have a pathophysiological role in the course of the disease. Inactive patients showed no significant elevation of serum sIL-2R levels over control subjects.

IL-6 $(26 \mathrm{kDa})$ is a multifunctional pro-inflammatory cytokine with its important role in the regulation of immune response. ${ }^{28}$ It is produced by monocytes, epithelial cells and fibroblasts, and causes polyclonal B-cell activation, hypergammaglobulinaemia, and autoantibody production with T-cell activation. ${ }^{29}$ The major effect of IL- 6 described is the proliferation and differentiation of cells, as well as increasing secretion of acute-phase proteins by the liver. ${ }^{27}$ It has also been reported that IL-6 induces uveitis in vivo in rats when injected intracamerally. ${ }^{30}$ Abnormal IL-6 production has been implicated in some autoimmune diseases and chronic inflammatory reactions. ${ }^{31}$ Our study showed that patients with BD had significantly elevated IL-6 levels compared with control subjects, with the highest values observed in the active period of the disease. In addition, even inactive patients with BD had significantly higher IL-6 levels when compared with control subjects. Since IL-6 is a key activator of the acute-phase response and implicated in liver synthesis of acute-phase reactants, ${ }^{31}$ it is likely to play an important role in the course of BD.

IL-8, a chemokine secreted from many cells including endothelial cells, lymphocytes, monocytes, macrophages and retinal pigment epithelial (RPE) cells, is one of the main chemoattractants for polymorphonuclear neutrophils (PMNs) and can also directly activate the PMNs itself. ${ }^{32,33}$ High levels of serum IL-8 have been detected in various diseases and suggested to be the marker of disease activity in sarcoidosis. ${ }^{34}$ This study also showed that IL-8 levels were significantly higher in patients with $\mathrm{BD}$ over control subjects. In addition, IL-8 levels were significantly higher in active $\mathrm{BD}$ patients when compared with inactive subjects. Since IL-8 has pro-inflammatory properties in the inflammatory response with its potent effect on neutrophils by attraction of PMNs into the lesions (a characteristic finding of BD), we think that IL-8 most probably participates during the course of BD. Considering the known properties of IL-8 as a chemoattractant and activator of neutrophils, the treatment of $\mathrm{BD}$ might be of immense value in the development of therapeutic regiments for managing the disease.

TNF $(17 \mathrm{kDa})$ is a cytokine secreted by lymphocytes and reticuloendothelial cells in many acute and chronic inflammatory diseases. ${ }^{31}$ TNF, like IL-6, is also a pro-inflammatory cytokine and is involved in the blood-retinal barrier breakdown by opening tight junctions of retinal vascular endothelial cells and RPE cells. ${ }^{35}$ The present study showed that TNF- $\alpha$ levels in the serum of patients with $\mathrm{BD}$ were significantly higher in active disease than inactive BD patients or control subjects. It is probable that the disease activity is associated with the secretion of proinflammatory mediators by direct activation of circulating monocytes. ${ }^{31}$

Increased free-radical production by activated neutrophils has been demonstrated in $\mathrm{BD} .{ }^{36}$ The burst of activated, oxygen-derived free radicals is responsible for cell membrane peroxidation, resulting in tissue oedema with enzyme and protein degradation. Lipid peroxidation, in turn, leads to the subsequent formation of free fatty acids and arachadonic acid. ${ }^{3} \mathrm{~A}$ vicious circle ensues, whereby the metabolism of these molecules leads to further free-radical formation and $\mathrm{OH}^{\bullet}$ generation, which may lead to further lipid peroxidation in cells and further oxidative damage. ${ }^{37}$ This study clearly found that lipid peroxidation, measured as MDA levels, was increased in patients with $\mathrm{BD}$, and that the levels were correlated with disease activity. Therefore, this may be responsible from the tissue damage in $\mathrm{BD}$ as well as endothelial dysfunction, which is the most characteristic feature of the disease. ${ }^{22,36}$ Defence systems of cells against this free-radical-induced toxic lipid peroxidation consist of antioxidant molecules. ${ }^{38}$ These molecules block the initiation of free-radical chain reactions, and therefore lipid peroxidation in cells.

Taken together, serum MDA, sIL-2R, IL-6, IL-8 and TNF- $\alpha$ levels were significantly higher in patients with active BD compared with inactive BD patients and healthy control subjects. We concluded that endothelial cells, PMNs and macrophages produced proinflammatory cytokines such as IL-1 $\beta$, IL-6, and TNF, and these cytokines possibly induced inducible NO synthase and, thereby, increased NO production. ${ }^{39}$ In fact, our another study demonstrated an increased total nitrite level (an indicator of NO production) in patients with BD when compared with control subjects with the highest level in the active BD patients. ${ }^{13}$ This most abundant free radical possibly induces oxidative stress and leads to the formation of self-propagating lipid peroxidation. On the contrary, our further study found higher homocysteine levels in patients with $\mathrm{BD},{ }^{12}$ which is known to be the potent 
inducer for IL-6, IL-8 and TNF- $\alpha .{ }^{14}$ Therefore, homocysteine $\rightarrow$ cytokine $\rightarrow$ leptin $\rightarrow$ nitric oxide $\rightarrow$ lipid peroxidation relationships during the course of $\mathrm{BD}$ are open to further in vivo and in vitro studies.

In conclusion, we observed increased mean levels of MDA, sIL-2R, IL-6, IL-8 and TNF- $\alpha$ in patients with BD over control subjects. Furthermore, sIL-2R, IL-6, IL-8 and TNF- $\alpha$ levels in patients with active BD were significantly higher than those in inactive patients, suggesting that these cytokines to be related with disease activity. These pro-inflammatory cytokines may play a role during the course of the disease and may be responsible for tissue damage by lipid peroxidation. Understanding the role of these low molecular weight proteins in a wider context should help us to clarify the role of the chemokine and cytokines in the aetiopathogenesis of $\mathrm{BD}$. Treatment of $\mathrm{BD}$ is presently difficult, partly because of the multisystem nature of the disease. Recent treatment modalities are encouraging, and it is probable that further treatment modalities that interfere with cell signalling processes may be the future direction for the clinical management of $\mathrm{BD}$. In addition, amelioration of clinical manifestations may be envisaged by targeting lipid peroxidation with dietary or pharmacological antioxidants.

ACKNOWLEDGEMENTS. The authors have no financial or proprietary interest in any instrument or products used in this study.

\section{References}

1. Balkwill FR, Burke F. The cytokine network. Immunol Today 1989; 10 299-304.

2. Hoekzema R, Murray PI, Kijlstra A. Cytokines and intraocular inflammation. Curr Eye Res 1990; 9: 207-211.

3. Halliwell B. Reactive oxygen species in living systems: source, biochemistry, and role in human disease. Am J Med 1991; 91: 14-22.

4. Ghate JV, Jorizzo JL. Beh et's disease and complex aphthosis. J Am Acad Dermatol 1999; 40: 1-18.

5. Beh et $\mathrm{H}$. Uber rezidivivierende Aphthose, durch ein Virus verursachte Geschwure am Mund, am Auge und an den Genitalien. Dermatol Wochenschr 1937; 105: 1152-1157.

6. Jorizzo JL, Hudson RD, Schmalstieg FC, et al. Beh et's syndrome: immune regulation, circulating immune complexes, neutrophil migration, and colchicine therapy. J Am Acad Dermatol 1984; 10: 205-214.

7. Evereklioglu C, Er H. Increased corneal thickness in active Beh et's disease. Eur J Ophthalmol 2002; 12: 24-29.

8. Evereklioglu C, Cokkeser Y, Doganay S, Er H, Kizilay A. Audio-vestibular evaluation in patients with Behçet's syndrome. J Laryngol Otol 2001; 115: 704-708.

9. Gunen H, Evereklioglu C, Kosar F, Er H, Kizkin O. Thoracic involvement in Beh et's disease and its correlation with multiple parameters. Lung 2000; 178: 161-170.

10. Evereklioglu $\mathrm{C}$, Yurekli M, Er H, et al. Increased plasma adrenomedullin levels in patients with Beh et's disease. Dermatology 2000; 201 : $312-315$.

11. Evereklioglu C, Inaloz HS, Kirtak N, et al. Serum leptin concentration is increased in patients with Beh et's syndrome and correlated with disease activity. BrJ Dermatol 2002; in press.

12. Er H, Evereklioglu C, Cumurcu T, et al. Serum homocysteine level is increased and correlated with endothelin- 1 and nitric oxide in Beh et's disease. BrJ Ophthalmol 2002; in press.
13. Evereklioglu C, Turkoz Y, Er H, Inaloz HS, Ozbek E, Cekmen M. Increased nitric oxide production in patients with Beh et's disease: is it a new activity marker? J Am Acad Dermatol 2002; 46: 50-54.

14. Ikeda U, Ikeda M, Minota S, Shimada K. Homocysteine increases nitric oxide synthesis in cytokine-stimulated vascular smooth muscle cells. Circulation 1999; 99: 1230-1235.

15. Ballow M, Nelson R. Immunopharmacology: immunomodulation and immunotherapy. JAMA 1997; 278: 2008-2017.

16. International Study Group for Beh et's Disease. Criteria for diagnosis of Beh et's disease. Lancet 1990; 335: 1078-1080.

17. Bloch-Michel E, Nussenblatt RB. International Uveitis Study Group recommendations for the evaluation of intraocular inflammatory disease. Am J Ophthalmol 1987; 103: 234-235.

18. Babson AL. The IMMULITE Automated Immunuassay System. $J$ Immunoassay 1991; 14: 83-88.

19. Berthier F, Lambert C, Genin C, Bienvenu J. Evaluation of an automated immunoassay method for cytokine measurement using the Immulite Immunoassay system. Clin Chem Lab Med 1999; 37: 593-599.

20. Wasowicz W, Neve J, Peretz A. Optimized steps in flourometric determination of thiobarbituric acid-reactive substances in serum: importance of extraction $\mathrm{pH}$ and influence of sample preservation and storage. Clin Chem 1993; 39: 2522-2526.

21. Wechsler B, Le Thi Huong Du LT, de Gennes C, et al. Arterial manifestations of Beh et's disease. 12 cases. Rev Med Interne 1989; 10: 303-311.

22. Sahin S, Akoglu T, Direskeneli H, Sen LS, Lawrence R. Neutrophil adhesion to endothelial cells and factors affecting adhesion in patients with Beh et's disease. Ann Rbeum Dis 1996; 55: 128-133.

23. di Giovine FS, Duff GW. Interleukin 1: the first interleukin. Immunol Today 1990; 11: 13-20.

24. Dinarello CA. Interleukin-1 and the pathogenesis of the acute-phase response. $N$ Engl J Med 1984; 311: 1413-1418.

25. Dinarello CA. Interleukin-1 and Interleukin-1 antagonism. Blood 1991; 77: 1627-1652.

26. Symons JA, Wood NC, Di Giovine FS, Duff GW. Soluble IL-2 receptor in rheumatoid arthritis. Correlation with disease activity, IL-1 and IL-2 inhibition. J Immunol 1988; 141: 2612-2618.

27. Kapp A, Piskorski A, Schopf E. Elevated levels of interleukin 2 receptor in sera of patients with atopic dermatitis and psoriasis. BrJ Dermatol 1988; 119: $707-710$.

28. Heinrich PC, Castell JV, Andus T. Interleukin-6 and the acute phase response. Biochem J 1990; 265: 621-636.

29. Hirano T. Interleukin- 6 and its relation to inflammation and disease. Clin Immunol Immunopathol 1992; 62: 60-65.

30. de Vos AF, Klaren VN, Kijlstra A. Expression of multiple cytokines and IL1RA in the uvea and retina during endotoxin-induced uveitis in the rat. Invest Ophthalmol Vis Sci 1994; 35: 3873-3883.

31. Evans CA, Jellis J, Hughes SP, Remick DG, Friedland JS. Tumour necrosis factor-alpha, interleukin-6, and interleukin-8 secretion and the acutephase response in patients with bacterial and tuberculous osteomyelitis. J Infect Dis 1998; 177: 1582-1587.

32. Baggiolini M, Walz A, Kunkel SL. Neutrophil-activating peptide-1/interleukin-8, a novel cytokine that activates neutrophils. J Clin Invest 1989; 84: 1045-1049.

33. Leonard EJ, Yoshimura T. Neutrophil attractant/activation protein-1 (NAP1 [interleukin-8]). Am J Respir Cell Mol Biol 1990; 136: 479-486.

34. Yokoyama T, Kanda T, Kobayashi I, Suzuki T. Serum levels of interleukin-8 as a marker of disease activity in patients with chronic sarcoidosis. $J$ Med 1995; 26: 209-219

35. de Vos AF, van Haren MA, Verhagen C, Hoekzema R, Kijlstra A. Kinetics of intraocular tumour necrosis factor and interleukin-6 in endotoxininduced uveitis in the rat. Invest Ophthalmol Vis Sci 1994; 35: 1100-1106.

36. Chambers JC, Haskard DO, Kooner JS. Vascular endothelial function and oxidative stress mechanisms in patients with Beh et's syndrome. $\mathrm{J} \mathrm{Am}$ Coll Cardiol 2001; 37: 517-520.

37. Christen WG Jr. Antioxidants and eye disease. Am J Med 1994; 97: $14-17$.

38. Guemouri L, Artur Y, Herbeth B, Jeandel C, Siest G. Biological variability of superoxide dismutase, glutathione peroxidase, and catalase in blood. Clin Chem 1991; 37: 1932-1937.

39. Nathan C, Xie QW. Nitric oxide synthasis: roles, tolls, and controls. Cell 1994; 78: $915-918$

Received 3 January 2002 Accepted 23 January 2002 


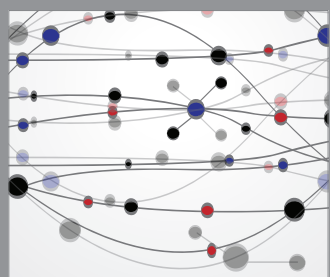

The Scientific World Journal
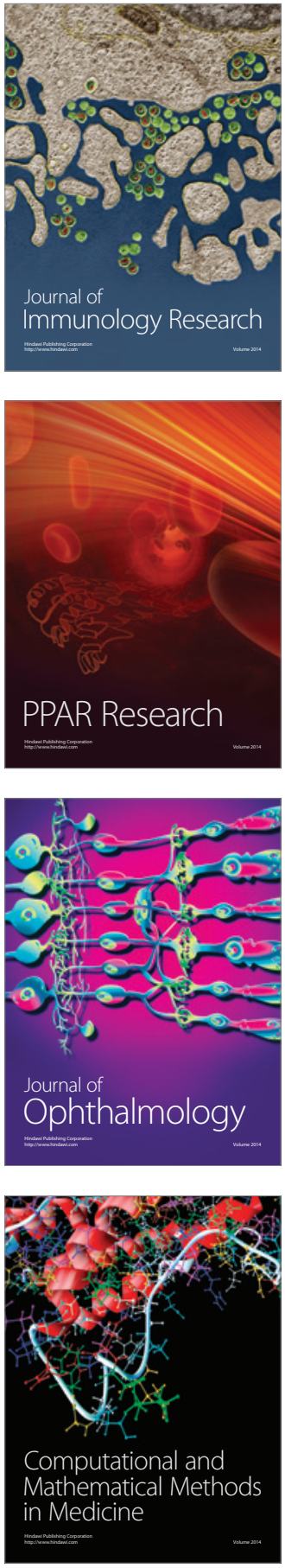

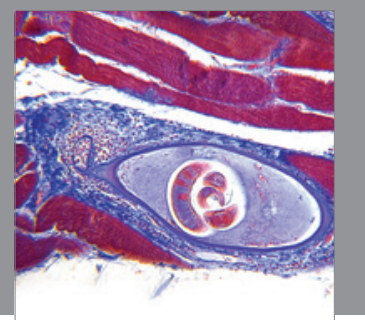

Gastroenterology

Research and Practice
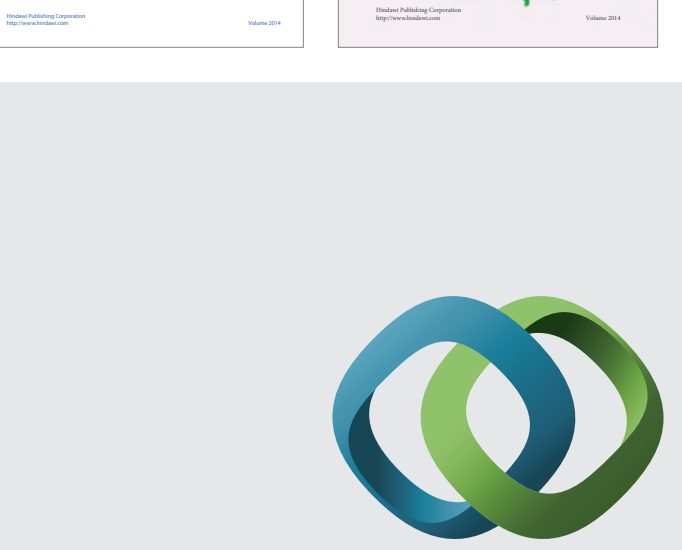

\section{Hindawi}

Submit your manuscripts at

http://www.hindawi.com
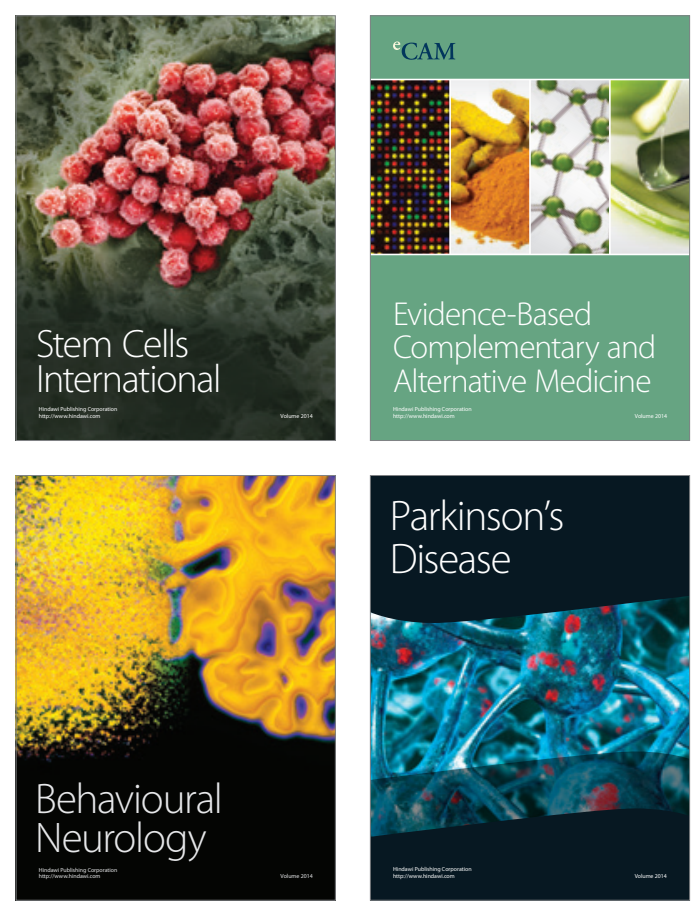

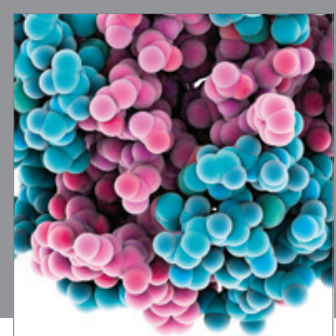

Journal of
Diabetes Research

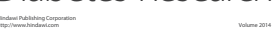

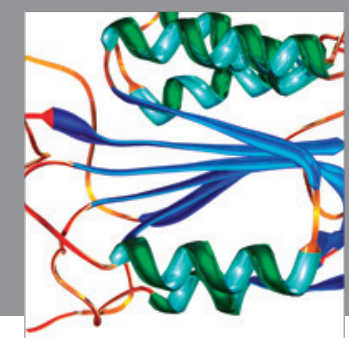

Disease Markers
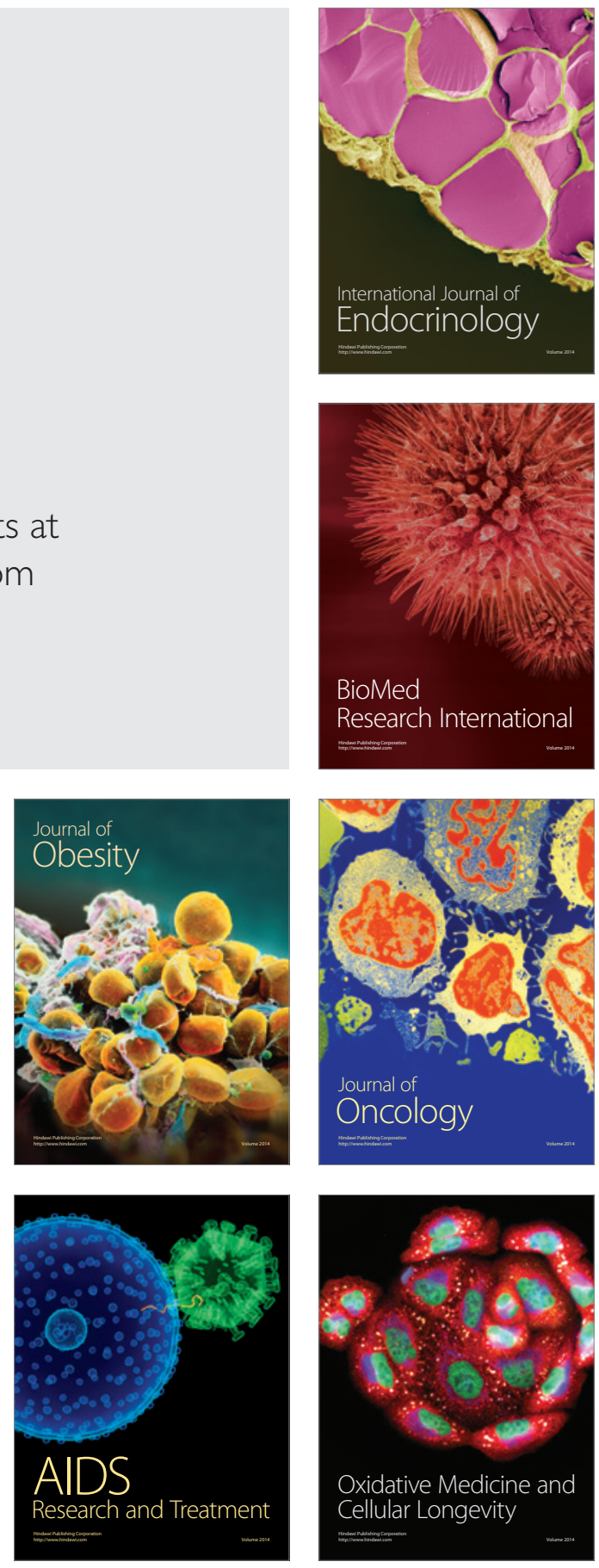